\title{
Enumeration of semen leucocytes by fluorescence in situ hybridisation technique
}

Division of Genetics, Long Island College Hospital-

SUNY Health Science Center at Brooklyn,

New York, USA

$R$ A Conte

$S$ Luke

R S Verma

Correspondence to

Prof Ram S Verma,

Division of Genetics, Long

Island College Hospital,

Hicks St at Atlantic Ave,

Brooklyn, NY 11201, USA

Accepted for publication

12 September 1995

R A Conte, S Luke, R S Verma

\begin{abstract}
Aim-To determine whether the fluorescent in situ hybridisation technique (FISH) using a total human DNA genomic probe can be used to enumerate semen leucocytes.

Methods-Semen samples from five donors were subjected to a mild $\mathrm{KCl}$ solution. These samples were then biotin labelled under FISH conditions using a total human DNA genomic probe and the leucocyte counts were determined. To check the accuracy of the technique a monoclonal antibody against the common leucocyte antigen CD45 [KC56(T-200)] served as a control. An isotypic control for $[\mathrm{KC} 56(\mathrm{~T}-200)]$, the immunoglobulin [MsIgG1], served as a secondary control. Results-Semen leucocytes stained by the FISH technique were easily detected because of their distinct bright yellow colour, while the sperm cells were red. The leucocyte count ranged from 0.5 to $4.9 \times 10^{6}$ per $\mathrm{ml}$ of semen. KC56(T-200) and its isotypic control MsIgG1, which served as control for the FISH technique, accurately identified $94 \%$ and $97 \%$ of the semen leucocytes of a control donor, respectively. Conclusions-The FISH technique using a total human DNA probe can accurately and effectively enumerate the overall leucocyte population in semen.
\end{abstract}

(f Clin Pathol: Mol Pathol 1995;48:M319-M321)

Keywords: Leucocytospermia, sperm, fluorescent in situ hybridisation.

Increased semen leucocyte counts have been correlated with inflammation and infection of male sex glands, asthenospermia, reduced sperm count, and infertility. ${ }^{1-6}$ The condition of leucocytospermia occurs when the leucocyte population exceeds $10^{6} \mathrm{per} \mathrm{ml}$ of semen. This condition may have characteristic infectious symptoms or a non-infectious origin and can be observed in fertile and infertile individuals. ${ }^{7-9}$ Activated leucocytes can produce cytotoxic effects which may reduce sperm motility, ${ }^{1011}$ and impede the sperm's ability to penetrate hamster zona-free ova ${ }^{1213}$ and human ova during in vitro fertilisation techniques. ${ }^{14} 15$ Semen macrophages have also played a role in phagocytosis of spermatozoa and have been associated with male infertility. ${ }^{1617}$ Round cells in human semen are mainly leucocytes or immature germ cells. ${ }^{18}$ It has been suggested ${ }^{19-21}$ that conventional semen staining techniques are unreliable in completely differentiating immature germ cells from leucocytes. ${ }^{122} 23 \mathrm{~A}$ need for a procedure that completely distinguishes semen leucocytes from immature germ cells in order to achieve an accurate leucocyte count warranted new procedures, which have been assessed for their suitability. ${ }^{24}$

This investigation examines a process that uses a biotin labelled probe under fluorescent in situ hybridisation conditions, where the ability to detect leucocytes depends upon favourable selective differences between the respective leucocyte and germ cell designs for organisation of the hierarchical DNA folding arrangements and its nuclear density, coupled with the permeability and expansion potential of the nuclear membrane. A FITC conjugated monoclonal antibody against the common leucocyte antigen CD45 [KC56(T-200)] served as a control for the detection of semen leucocyte populations because it can detect all leucocyte types in semen.

\section{Methods}

After a three day period of sexual abstinence, semen specimens from five donors were collected in sterile containers. The semen volume was measured. Semen was allowed to liquefy for 30 minutes, mixed gently, and a small volume used for routine determination of motility and sperm number per ml. Motility was determined after placing a small drop on a slide and sealing it under a glass coverslip. Progressive motility was noted after one hour and three hours and measured on a range from 0 to 4 . The sperm number per $\mathrm{ml}$ was calculated by diluting the semen using a white cell diluting pipette, with a standard dilution of 1:20, then counting the sperm in two leucocyte counting squares of a Neubauer chamber. ${ }^{25} 26 \mathrm{KCl}$ solution $(0.075 \mathrm{M})$ was added to the remaining semen in a ratio of $1: 3$, mixed, and then incubated at $37^{\circ} \mathrm{C}$ for 20 minutes. Immediately afterwards, $0.25 \mathrm{ml}$ of a methanol-glacial acetic acid fixative (3:1) was added and centrifuged at $1000 \mathrm{rpm}$ for five minutes. The pellets were fixed twice. The remaining pellets were suspended with $2 \mathrm{ml}$ of fixative per tube and dropped on precleaned slides. The slides were aged at room temperature for two days. The biotin labelled total human DNA genomic painting probe (Oncor) was performed as suggested by the manufacturer. The probes were biotin labelled, detected with fluorescein labelled avidin, and counterstained with propidium iodide.

The leucocyte number was calculated by separately counting the total number of sperm and leucocytes in 25 consecutive $250 \times$ magnification fields on the FISH slides and routine control slides for each donor. The leucocyte number was divided by the sperm number, and this ratio was multiplied by the sperm number per $\mathrm{ml}$ to determine the leucocyte number per 
Semen indices

\begin{tabular}{|c|c|c|c|c|c|c|}
\hline Donor & 1 & 2 & 3 & 4 & 5 & 6 \\
\hline Volume (ml) & $4 \cdot 5$ & $2 \cdot 5$ & $2 \cdot 5$ & $4 \cdot 0$ & $3 \cdot 0$ & $2 \cdot 5$ \\
\hline Motility (0-4) & 3 & 3 & 2 & 3 & 2 & \\
\hline Sperm count $\left(10^{6} / \mathrm{ml}\right)^{2}$ & 125 & 100 & 80 & 95 & 60 & 80 \\
\hline Leucocyte/sperm ratio $^{b}$ & 0.039 & 0.026 & 0.006 & 0.029 & 0.042 & 0.0094 \\
\hline Leucocytes $\left(10^{6}\right) / \mathrm{ml} \mathrm{semen}^{\mathrm{c}}$ & $4 \cdot 9$ & $2 \cdot 6$ & $0 \cdot 5$ & $2 \cdot 8$ & $2 \cdot 5$ & $0 \cdot 75$ \\
\hline
\end{tabular}

${ }^{\text {a }}$ Routine methods; ${ }^{\mathrm{bc}}$ FISH method.

$\mathrm{ml}$ of semen. ${ }^{27}$ In order to check the specificity of the probe to detect only the semen leucocytes, a FITC labelled monoclonal antibody against the common leucocyte antigen CD45 [Coulter clone KC56 (T-200)] was used as a control for 100 cells in a staining sequence preceeding the FISH technique. The isotypic immunoglobulin [MsIgG1] which is a control for the KC56(T-200) (Coulter) served as a secondary control for an additional 100 cells. In addition, a sixth donor served as a control using the FISH technique and the results were then compared to those obtained using the two immunocytochemicals.

\section{Results}

The sperm counts of the five donors ranged from 60 to $125 \times 10^{6}$ per $\mathrm{ml}$ semen. The leucocyte numbers using FISH ranged from 0.5 to $4.9 \times 10^{6}$ per $\mathrm{ml}$ semen (table). Observation of semen leucocyte populations at $250 \times$ magnification was easily detected because they were displayed as bright yellow to green, while the sperm was red. Examples of the leucocyte population were observed at $1250 \times$ (figure). A sixth donor was used as a control to compare semen leucocytes stained by FISH with those stained by the immunocytochemicals

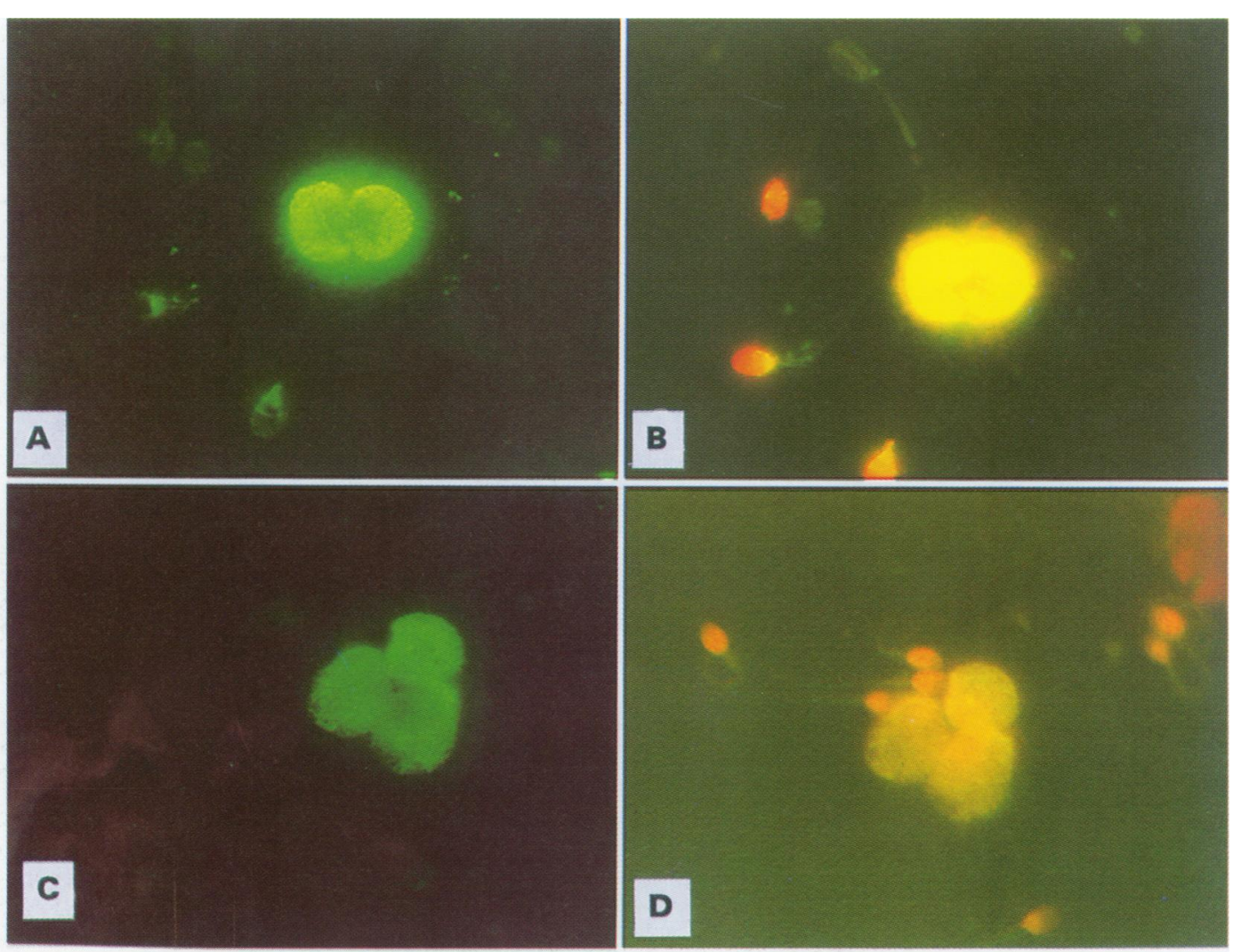

[KC56(T-200)] and [MsIgG1]. The FISH results for semen leucocytes were $0.75 \times 10^{6} / \mathrm{ml}$; KC56(T-200) was $0.79 \times 10^{6} / \mathrm{ml}$ and MsIgG1 was $0.77 \times 10^{6} / \mathrm{ml}$. In addition, a sequential control system showed that the FISH technique accurately determined 95 of 100 cells first determined by KC56(T-200) to be leucocytes (95\%). The isotypic [MsIgG1] control system confirmed that $98 \%$ of the leucocytes detected by FISH technique were leucocytes.

\section{Discussion}

Presently, there is no analytical method to calculate sperm performance that will precisely determine male infertility, except in conditions where all sperm are aberrant. ${ }^{28-30}$ The majority of males who are tested for infertility either have low sperm count, asthenospermia, or abnormal morphology, and these often occur in combination. ${ }^{30}$ Leukocytospermia has been correlated with male infertility. ${ }^{931}$ Lymphokines and monokines produced by certain activated leucocytes have been responsible for cytotoxic effects on sperm under in vitro conditions and are believed to reduce sperm motility and have adverse effects on fertility. ${ }^{1013}$ The duration of action and concentration of released cytokines, the sperm's proximity to the activated leucocytes in the male genital tract, and the quantity and type of leucocytes are all variables that affect the sperm. ${ }^{1011}$ The epididymis is a site for sperm storage and passage where sperm can be susceptible to chemotactic and phagocytic effects $^{9323}$ that are most likely to be from granulocytes, monocytes/macrophages, and lymphocytes. ${ }^{1}$ If an increased round cell population in semen is composed of leucocytes this

Semen leucocytes revealed by a monoclonal antibody against the common leucocyte antigen $C D 45(A, C)$ and sequentially detected by a total human DNA genomic painting probe $(B, D)(1250 \times)$. 
may indicate a genital infection or there may be a subclinical cause; if the round cells are immature germ cells the cause is likely to be incomplete spermatogenesis. ${ }^{9}$ Routine semen staining procedures ${ }^{19-21}$ have not been completely reliable in distinguishing immature germ cells from leucocytes. ${ }^{1222331}$

Under specific conditions, the biotin labelled probe can selectively detect semen leucocytes, thus allowing them to be counted. A FITC conjugated monoclonal antibody against the common leucocyte antigen CD45, and its isotypic control (MsIgG1), which are able to detect $\mathrm{T}$ and B lymphocytes, monocytes, macrophages, granulocytes, thymocytes, and bone marrow cells, served as controls for the detection of semen leucocyte populations and confirmed the accuracy of the FISH technique. The reason why the semen leucocyte counts were slightly lower with FISH than with the immunocytochemical controls may be due to incomplete probe hybridisation with its target leucocyte DNA.

In order for a molecular probe to enter and hybridise with sperm DNA, it has to pass through its protective membrane. Lithium salts have been used successfully to expand the sperm membrane, allowing the probe to enter and hybridise. ${ }^{34}$ If $\mathrm{KCl}$ is used, as described here, the sperm membrane will not expand sufficiently, preventing entrance and ultimately hybridisation of the probe. However, the leucocyte nuclear membrane will expand and the probe may enter and hybridise with the cell's DNA, allowing detection. The nuclear density of mammalian sperm DNA is six times more condensed than the DNA in mitotic genomes, and sperm chromatin organisation of protamines, which packages the DNA more compactly than any eukaryotic DNA, contains a vast network of disulphide bridges ${ }^{35} 36$ which must be reduced by strong agents to allow molecular probes to hybridise once they pass through the nuclear membrane. ${ }^{34}$ Also, the sperm nucleus plays an integral part in the design of this highly compact DNA organisation. ${ }^{37}$ These conditions have been considered obstacles in previous semen genomic DNA in situ hybridisation studies. The overall differences in the design of hierarchical DNA organisation and packaging of these two cell types apparently favoured leucocyte detection with the biotin labelled probe and allowed the enumeration of semen leucocytes.

We thank Michael W Lazar for the excellent photographs and JoLee M Pixley for her typing assistance.

1 Wolff $\mathrm{H}$, Anderson DJ. Immunohistological characterization and quantification of leucocyte subpopulations in human semen. Fertil Steril 1988;49:497-504.

2 Gorini G, Milano F, Olliaro P, Ragazzetti A, Rondanelli EG. Chlamydia trachomatis infection in primary unexplained infertility. Eur F Epidemiol 1990;6:335-8.

3 Mazzolli A, Barrera C, Salama E, Kortebani G. Percoll separation and functional study of semen round cells from asthenozoospermic men with infection history. In: Alexander NJ, Griffin D, Speiler JM, Waites GMH, eds. Gamete interaction: prospects for immunocontraception. New York: Wiley-Liss, 1990.

4 Peek JC, Graham FM, Hookman A. Prevalence of Chlamydial antibodies in women with tubal disease: impact of Chlamydia trachomatis on the demand for in vitro fortilization. N Z Med F 1990;103:63-5.

5 Christiansen E, Tollefsrud A, Purvis K. Sperm quality in men with chronic abacterial prostaovesiculitis verified by rectal with chronic abacterial prostaovesiculitis ver.
6 Kortebani G, Gonzales GF, Barrera C, Mazzolli AB. Leukocyte populations in semen and male accessory gland function: relationship with antisperm antibodies and semen quality. Andrologia 1992;24:197-204.

7 El-Demiry MIM, Hargreave TB, Busuttil A, James K, Chisholm GD. Identifying leukocytes and leucocyte subpopulations in semen using monoclonal antibody probes. populations in semen usin

8 Gonzales GF, Garcia-Hijarles MA, Gutierrez R, GuerraGarci R. The secretory activity of semen vesicles and its relationship with sperm motility: effects of infection in the relationship with sperm motility: effects of infection in the
male reproductive tract. Int $\mathcal{F}$ Androl 1989;12:286-94.

male reproductive tract. Int $\mathcal{F}$ Androl 1989;12:286-94.
Wolff H, Politch JA, Martinez A, Haimovici F, Hill JA, Anderson DJ. Leukocytospermia is associated with poor semen quality. Fertil Steril 1990;53:528-36.

10 Hill JA, Haimovici F, Politch JA, Anderson DJ. Effects of soluble products of activated lymphocytes and macrophages (lymphokines and monokines) on human sperm motion parameters. Fertil Steril 1987:47:460-5.

11 Anderson DJ, Hill JA. Cell-mediated immunity in infertility. Am $\mathcal{F}$ Reprod Immunol Microbiol 1988;17:22-30.

12 Maruyama DK, Hale RW, Rogers BJ. Effects of white blood cells on the in vitro penetration of zona-free hamster eggs cells on the in vitro penetration of zona-free ham

13 Hill JA, Cohen J, Anderson DJ. The effects of lymphokines and monokines on human sperm fertilizing ability in the zona-free hamster egg penetration test. Am F Obstet Gynecol 1989;160:1154-9.

14 Cohen J, Edwards R, Fehilly C, Fishel S, Hewitt J, Purdy J, et al. In vitro fertilization: a treatment for male infertiity. Fertil Steril 1985;43:422-32.

15 Talbert LM, Hammond MG, Halme J, O'Rand M, Fryer JG, Ekstrom RD. Semen parameters and fertilization of human oocytes in vitro: a multivariable analysis. Fertil Steril 1987; 0ocytes in

16 London SN, Haney AF, Weinberg JB. Macrophages and infertility: enhancement of human macrophage-mediated sperm killing by antisperm antibodies. Fertil Steril 1985;43: 274-8.

17 Smith DC, Barratt CLR, Williams MD. The characterization of non-sperm cells in ejaculates of fertile men using transmission electron microscopy. Andrologia 1989;21:319-33.

18 World Health Organisation. WHO laboratory manual for the examination of human semen and semen-cervical mucus interaction. In: Belsey MA Eliasson R, Gallegos AJ, Moghissi KS, Paulsen CA, Prasad MRN, eds. Singapore: Press Concern, 1980:18.

19 Endtz AW. A rapid staining method for differentiating granulocytes from "germinal cells" in Papanicolaou-stained ulocytes from "germinal cells"
semen. Acta Cytol 1974;18:2-7.

20 Couture M, Ulstein M, Leonard J, Paulsen CA. Improved staining method for differentiating immature germ cells from white blood cells in human semen fluid. Andrologia 1976;8:61-6.

21 World Health Organisation. WHO laboratory manual for the examination of human semen and semen-cervical mucus interaction, 2nd ed Cambridge: Press Syndicate of the University of Cambridge, 1987:2.

22 Nahoum CRD, Cardozo D. Staining for volumetric count of leukocytes in semen and prostate-vesicular fluid. Fertil Steril 1980;34:68-9.

23 Eggert-Kruse W, Bellman A, Rohr G, Tilgen W, Runnebaum $B$. Differentiation of round cells in semen by means of monoclonal antibodies and relationship with male fertility. Fertil Steril 1992;58:1046-55.

24 Wolff H, Panhans A, Zebhauser M, Meurer M. Comparison of three methods to detect white blood cells in semen: leukocyte esterase dipstick test, granulocyte elastase enzymeimmunoassay, and peroxidase cytochemistry. Fertil Steril 1992;58:1260-2.

25 Glasser L. Semen fluid and subfertility. Diagn Med 1981;4: $28-45$.

26 Strasinger SK. Urinalysis and body fluids: a self-instructional test. Philadelphia: FA Davis Co, 1985:141-87.

27 Burger RE, Karp LE, Williamson RA, Koehler J, Moore DE, Homes KK. The relationship of pyospermia and semen fluid bacteriology to sperm function as reflected in the sperm penetration assay. Fertil Steril 1982;37:557-64.

28 Aitken RJ, Ross A, Lees MM. Analysis of sperm function in Kartagener's syndrome. Fertil Steril 1993;40:696-8.

29 Jeyendarn RS, Van Der Ven HH, Kennedy WP, Heath E, Perez-Pelaez M, Sobrero AJ, et al. Acrosomeless sperm, a cause of primary male infertility. Andrologia 1985;17:31-6.

30 Liu DY, Baker HWG. Test of human sperm function and fertilization in vitro. Fertil Steril 1992;58:465-83.

31 Wolff $\mathrm{H}$. The biological significance of white blood cells in semen. Fertil Steril 1995;63:1143-57.

32 Wang YF, Holstein AF. Intraepithelial lymphocytes and macrophages in the human epididymis. Cell Tissue Res 1983; 233:517-21.

33 Wilton LJ, Temple-Smith PD, Baker HWG, de Kretser DM. Human male infertility caused by degeneration and death of sperm in the epididymus. Fertil Steril 1988;49:1052-8.

34 Wyrobek AJ, Alhborn T, Balhorn R, Stanker L, Pinkel D. Fluorescence in situ hybridization to $\mathrm{Y}$ chromosomes in decondensed human sperm nuclei. Mol Reprod Devel 1990; 27:200-8.

35 Pogany GC, Corzett M, Weston S, Balhorn R. DNA and protein content of mouse sperm: implication regarding sperm chromatin structure. Exp Cell Res 1981;135:127-36. malian. A model for the structure of chrom

37 Ward WS, Coffey DS. DNA packaging and organization in mammalian spermatozoa: comparison with somatic cells. Biol Reprod 1991;44:569-74. 